\title{
Uji Pendahuluan Efek Fungisida Bunga Kembang Telang (Clitoria ternatea L.) terhadap Jamur Fusarium oxysporum f.sp. cepae Penyebab Penyakit Moler pada Bawang Merah
}

\author{
Tarkus Suganda ${ }^{1}$, dan Satryo Restu Adhi $^{2}$ \\ ${ }^{1}$ Dosen, ${ }^{2}$ Mahasiswa Program Magister, Departemen Hama dan Penyakit Tumbuhan \\ Fakultas Pertanian Universitas Padjadjaran \\ Alamat korespondensi: tarkus.suganda@unpad.ac.id
}

\begin{abstract}
Preliminary study on the fungicidal effect of butterfly pea flower (Clitoria ternatea L.) against Fusarium oxysporum f.sp. cepae, the causal agent of moler diseases on shallot
\end{abstract}

Butterfly pea (Clitoria ternatea) has been known worldwide to possess numerous anti microbe substances, both against bacteria, fungi, nematodes, and insects. Researches were mostly conducted against human microbial pathogens, whereas only a few against plant pathogens, especially in Indonesia. A preliminary study has been carried out to reveal the fungicidal effects of flower extract in inhibiting the in-vitro growth of Fusarium oxysporum f.sp. cepae (FOC), the causal agent of moler diseases, one of the most destructive diseases on shallot. Results showed that the boiling extract of flower of butterfly pea at $5 \%$ concentration inhibited $46 \%$ the growth of FOC over control.

Key words: Fungicidal effect, Cliteria ternatea, Fusarium oxysporum f.sp. cepae, In-vitro

\section{ABSTRAK}

Kembang telang (Clitoria ternatea) sudah lama dikenal di seluruh dunia mengandung berbagai senyawa antimikroba, baik terhadap bakteri, jamur, nematoda. bahkan insekta. Target utama patogen yang banyak diteliti adalah terhadap patogen penyakit pada manusia. Penelitian terhadap patogen tanaman, terutama di Indonesia masih sangat kurang. Uji pendahuluan sudah dilakukan untuk mengetahui efek fungisidal bunga kembang telang dalam menghambat pertumbuhan invitro jamur Fusarium oxysporum f.sp. cepae (FOC), penyebab penyakit moler yang sangat merugikan pada tanaman bawan merah. Hasil pengujian menunjukkan bahwa air rebusan bunga kembang telang memiliki kemampuan dalam menghambat pertumbuhan biakan FOC. Pada konsentrasi 5\%, efek penghambatannya mencapai $46 \%$ terhadap kontrol.

Kata kunci: Efek fungisida, Cliteria ternatea, Fusarium oxysporum f.sp. cepae, In-vitro

\section{PENDAHULUAN}

Kembang telang (Clitoria ternatea L.) merupakan salah satu tanaman Leguminosae yang ditemukan di berbagai negara di dunia (NPGS, 2008). Tanaman yang diduga berasal dari Asia tropis ini (Alderete-Chavez et al., 2011) tumbuh baik pada berbagai kisaran jenis tanah, toleran terhadap kelebihan hujan maupun kekeringan.
Kembang telang banyak diekplorasi dan menunjukkan sangat potensial untuk meningkatkan kesehatan manusia. Ekstrak tanaman kembang telang dilaporkan dapat digunakan untuk meningkatan daya ingat dan kemampuan otak (Jain et al., 2003; Rai et al., 2002); menurunkan tekanan darah, anti kecemasan, anti asma, dan penghilang rasa sakit (Sears, 2017), dan anti tumor (Sen et al., 2013). Selain itu, ekstrak tanaman kembang telang 
juga sudah dilaporkan efektif untuk mengobati berbagai penyakit pada manusia, antara lain sebagai anti jamur (Ajesh \& Sreejith, 2014; Kelemu et al., 2005; Neela et al., 2014); sebagai anti radang dan pereda nyeri (Shyamkumar \& Ishwar, 2012); dan antibakteri (Anand et al., 2011). Kamilla et al. (2009) menguji ekstrak metanol dari daun, batang, bunga, biji, dan akar kembang telang terhadap 12 spesies bakteri, 2 spesies ragi, dan 3 spesies jamur denga metode difusi agar dan dilusi. Hasilnya menunjukkan bahwa ekstrak daun dan akar merupakan ekstrak yang paling efektif terhadap semua organisme uji. Namun demikian, sejauh ini belum dilaporkan bagaimana keefektifan ekstrak tanaman kembang telang terhadap patogen secara in vitro apalagi untuk mengendalikan penyakit pada tanaman secara in vivo, baik di luar negeri apalagi di Indonesia.

Mengingat bahwa ekstrak tanaman kembang telang memiliki efek antimikroba yang merupakan patogen penyebab penyakit pada manusia, sangat menarik jika efek ekstrak tanaman kembang telang juga diujicoba sebagai antimikroba pada patogen penyebab penyakit tanaman. Tulisan ini merupakan hasil uji pendahuluan secara in vitro ekstrak air atau lebih tepatnya air seduhan bunga kembang telang, dalam menghambat pertumbuhan dan perkembangan jamur Fusarium oxysporum f.sp. cepae, (FOC) penyebab penyakit moler pada tanaman bawang merah.

FOC pada bawang merah merupakan salah satu penyakit yang sangat merugikan dan karena bersifat tular-tanah (soilborne), bahkan fungisida sintetik pun tidak efektif, tidak efisien, tidak fisibel untuk digunakan, serta sangat berbahaya, baik terhadap lingkungan maupun kesehatan manusia (Agrios, 2005).

\section{BAHAN DAN METODE}

Percobaan dilaksanakan di Laboratorium Fitopatologi Departemen Hama dan Penyakit Tumbuhan Fakultas Pertanian Universitas Padjadjaran di Jatinangor, dari bulan Oktober sampai dengan Desember 2017. Perobaan menggunakan metode eksperimental yang terdiri atas 5 perlakuan dengan 5 ulangan. Bagian tanaman kembang telang yang diujicobakan adalah bunganya. Bunga kembang telang dipilih karena merupakan bagian salah satu dari tanaman kembang telang yang memiliki kandungan antimikroba yang cukup tinggi (Kamilla et al., 2009). Selain itu, proses pembuatan seduhannya cukup sederhana dan cepat.
Mengingat bahwa koleksi aksesi yang ada di Fakultas Pertanian Universitas Padjadjaran belum dapat digunakan karena masih diutamakan untuk memperoleh biji, maka bunga kembang telang yang digunakan diperoleh dari sebuah perusahaan penjual kembang telang kering di Kediri.

\section{Pembuatan Bahan Percobaan}

Konsentrasi ekstrak yang dibuat adalah konsentrasi $1 \%, 2 \%, 3 \%, 4 \%$ dan 5\%. Konsentrasi tersebut dibuat menggunakan pelarut akuades steril. Pembuatan larutan konsentrasi $1 \%, 2 \%, 3 \%$, dan $4 \%$ ekstrak daun kembang telang untuk volume $20 \mathrm{ml}$ adalah dengan menimbang $0,2 \mathrm{~g}, 0,4 \mathrm{~g}, 0,6 \mathrm{~g}, 0,8 \mathrm{~g}$, dan $1 \mathrm{~g}$ bunga kembang telang, kemudian dimasukan ke dalam erlenmeyer dan ditambahkan pelarut akuades steril sebanyak $20 \mathrm{ml}$ kemudian direbus selama 5 menit dalam suhu $100^{\circ} \mathrm{C}$. Selanjutnya ekstrak bunga disaring menggunakan filter paper dan saringan bakteri.

Adapun perlakuan percobaan yang

digunakan adalah sebagai berikut :

1. Konsentrasi $0 \%$ (aquadest steril) + jamur Fusarium oxysporum f.sp. cepae.

2. Konsentrasi $1 \%+$ jamur Fusarium oxysporum f.sp. cepae.

3. Konsentrasi $2 \%+$ jamur Fusarium oxysporum f.sp. cepae.

4. Konsentrasi 3\% + jamur Fusarium oxysporum f.sp. cepae.

5. Konsentrasi $4 \%+$ jamur Fusarium oxysporum f.sp. cepae.

Isolat jamur Fusarium oxysporum f.sp. cepae (FOC) yang digunakan berasal dari Kabupaten Cirebon yang merupakan koleksi Laboratorium Fitopatologi Departemen Hama dan Penyakit Tumbuhan Fakultas Pertanian Universitas Padjadjaran.

\section{Uji Daya Hambat Secara In-Vitro}

Dari larutan stok masing-masing konsentrasi $(1 \%, 2 \%, 3 \%, 4 \%, 5 \%)$ diambil $1 \mathrm{ml}$ menggunakan pipet dan dimasukan kedalam cawan petri, kemudian ke dalam cawan petri ditambahkan media umum Potato Dextrose Agar (PDA) sebanyak $9 \mathrm{ml}$. Selanjutnya petri yang sudah terisi larutan ekstrak dan media Potato Dextrose Agar (PDA) digoyangkan hingga tercampur merata atau homogen. Setelah medium PDA mengeras, ke atas permukaan agar ditempatkan biakan jamur FOC yang diambil dari biakan menggunakan pembor gabus. Biakan kemudian diinkubasikan hingga 
jamur pada perlakuan 0\% (aquades steril/kontrol) memenuhi semua media pada cawan petri (Rao et al., 2016).

Untuk melihat daya hambat dari ekstrak bunga kembang telang terhadap pertumbuhan dan perkembangan FOC, dilakukan dengan menghitung diameter koloni jamur setiap hari menggunakan penggaris hingga koloni jamur pada perlakuan $0 \%$ penuh. Adapun rumus untuk menghitung persentase penghambatan digunakan rumus berikut :

Penghambatan $=$

Diameter kontrol - diameter perlakuan

Diameter kontrol

Data hasil pengujian tidak dianalisis secara statistik karena pada perlakuan konsentrasi 3\%, semua perlakuan terkontaminasi oleh bakteri .

\section{HASIL DAN PEMBAHASAN}

Dari Tabel 1 dapat dilihat bahwa bunga kembang telang memiliki kemampuan untuk menghambat perkembangan koloni jamur FOC secara in-vitro. Semakin tinggi konsentrasi air rebusan bunga kembang telang, semakin besar efek penghambatannya. Dalam pengujian ini, konsentrasi 5\% mampu menghambat perkembangan koloni FOC sebesar 46,15\%. Hasil uji pendahuluan ini mendukung berbagai informasi sebelumnya bahwa hampir semua bagian tanaman kembang telang memiliki efek antimikroba (Ajesh \& Sreejith, 2014; Kelemu et al., 2005; Neela et al., 2014; Anand et al., 2011; dan Kamilla et al. 2009).

Tabel 1. Perkembangan diameter koloni jamur Fusarium oxysporum f.sp. cepae pada medium PDA yang diberi perlakuan air rebusan bunga kembang telang berbagai konsentrasi.

\begin{tabular}{ccccccccc}
\hline \multirow{2}{*}{$\begin{array}{c}\text { Konsentrasi } \\
(\%)\end{array}$} & \multicolumn{9}{c}{ Diameter koloni $(\mathrm{cm})$ pada pengamatan hari ke- setelah inokulasi } & \multicolumn{2}{c}{ Penghambatan } \\
\cline { 2 - 6 } & 1 & 2 & 3 & 4 & 5 & 6 & 7 & $(\%)$ \\
\hline 0 & 1,80 & 2,60 & 4,20 & 5,80 & 7,45 & 7,80 & 8,45 & 0 \\
1 & 1,00 & 2,90 & 4,14 & 5,45 & 6,55 & 7,65 & 8,25 & 2,37 \\
2 & 1,25 & 3,10 & 4,00 & 5,50 & 5,35 & 5,75 & 5,85 & 30,77 \\
3 & 1,00 & 3,15 & 3.98 & 5,75 & terkontaminasi bakteri & - \\
4 & 1,15 & 3,30 & 3,99 & 5,45 & 6,00 & 6,55 & 6,70 & 20,71 \\
5 & 1,25 & 3,20 & 3,86 & 4,35 & 4,45 & 4,6 & 4,55 & 46,15 \\
\hline
\end{tabular}

Efek penghambatan yang diperlihatkan oleh air rebusan bunga kembang telang diduga disebabkan karena bunga kembang telang juga mengandung berbagai senyawa antimikroba. AlSnafi (2013) menyatakan bahwa kembang telang mengandung tannins, phlobatannin, carbohydrates, saponins, triterpenoids, phenols, flavanoids, flavonol glycosides, proteins, alkaloids, antharaquinone, anthocyanins, cardiac glycosides, Stigmast-4-ene-3,6-dione, volatile oils dan steroids. Beberapa dari senyawa kimia tersebut memang diketahui memiliki efek fungisida, contohnya saponin (Suzuki et al., 2007; Jin \& Yang, 2003); flavonoid (de Oliviera Filho et al., 2017), dan fenols (Alves et al., 20140.
Gambar 1 memberikan visualisasi tentang bagaimana perbedaan antara berbagai perlakuan konsentrasi yang diuji. Sampai pada hari ke-7 setelah perlakuan penempatan biakan FOC pada PDA, terlihat bahwa pertumbuhan koloni FOC pada perlakuan konsentrasi 5\% cukup terhambat.

Hasil uji pendahuluan ini dapat menjadi titik awal untuk melakukan uji yang lebih intensif mengenai efek dari kandungan tanaman kembang telang sebagai bahan untuk mengendalikan patogen penyakit tanaman. Penelitiannya masih sangat terbuka lebar, baik dari segi target patogen sasaran, konsentrasi efektifnya, maupun dalam hal cara ekstraksi dan pengaplikasiannya. Hasil uji pendahuluan ini yaitu berupa efek fungisidal telah sejalan dengan temuan Kelemu et al. (2005), 
Kamilla et al. (2009a, b) dan Neela et al. (2014), perlu untuk dicoba efek bakterisidalnya sebagaimana dilaporkan oleh Anand et al. (2011), Kamilla et al. (2009a) dan lainnya. Potensinya sebagai insektisida botani juga perlu dilakukan, karena menurut Mensah et al. (2014) dan Al-Snafi (2016), kembang telang juga memiliki efek insektisidal. Sementara untuk penelitian bahan aktifnya, mungkin sudah sangat banyak kepustakaan yang tersedia.

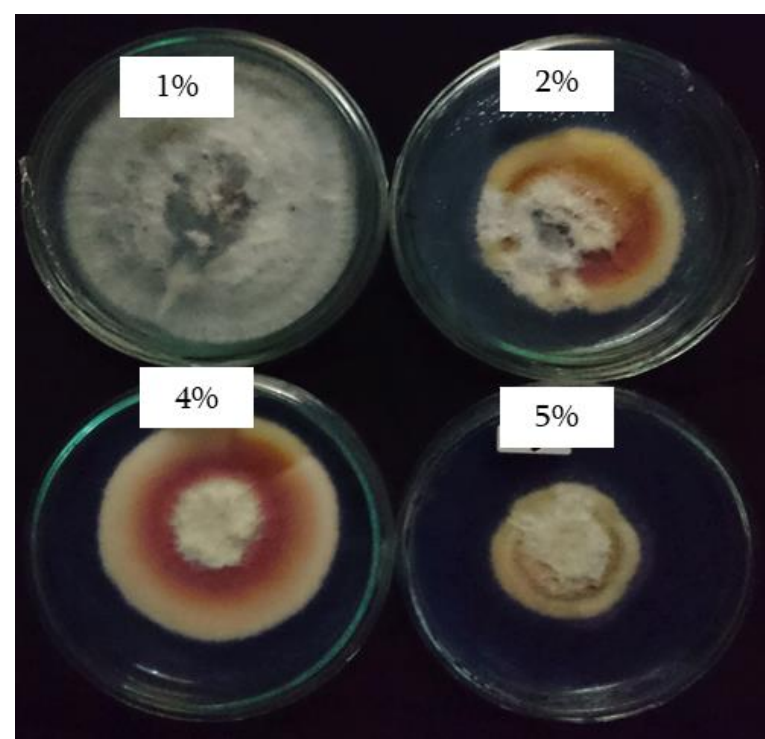

Gambar 1. Visualisasi pertumbuhan koloni FOC pada PDA yang diberi berbagai konsentrasi air rebusan bunga kembang telang (Konsentrasi 3\% tidak ditampilkan karena terkontaminasi bakteri).

Di Indonesia, kembang telah belum banyak dimanfaatkan, karena belum banyak kajian tentang kembang telang dan potensi pemanfaatannya. Sejauh ini pemanfaatan kembang telang di Indonesia antara lain baru untuk makanan ternak (Nulik, 2009; Sutedi, 2013) yang dapat meningkatkan kandungan lemak dan total padatan pada sapi perah dan dapat meningkatkan kualitas semen pada domba jantan. Belum ada laporan di Indonesia tentang pemanfaatan kembang telang sebagai fungisida.

Potensi ekonomi terbesar dari tanaman kembang telang sebenarnya selain sebagai bahan baku obat, juga sebagai pewarna alami. Kebutuhan pasar dunia terhadap zat anthocianin dari kembang telang diperkirakan mencapai 10.000 ton setiap tahunnya (Syazwani bt. Sapiee, 2013). Ditambah dengan potensinya sebagai bahan pengendali nabati bagi patogen penyebab penyakit tanaman, tanaman kembang telang menjanjikan prospek yang baik dalam mengendalikan penyakit tanaman yang selain efektif namun juga ramah lingkungan, terutama untuk patogen-patogen yang sulit atau dilarang dikendalikan adengan fungisida sintetik.

\section{SIMPULAN}

Bunga tanaman kembang telang memperlihatkan kemampuan dalam menghambat secara in vitro pertumbuhan biakan jamur Fusarium oxysporum f.sp. cepae (FOC) penyebab penyakit moler pada tanaman bawang merah. Pada konsentrasi 5\%, efek penghambatannya mencapai $46 \%$ terhadap kontrol.

\section{DAFTAR PUSTAKA}

Agrios, GN. 2005. Plant Pathology 5th ed. Elsevier Academic Press.

Ajesh, K and K Sreejith. 2014. A novel antifungal protein with lysozyme-like activity from seeds of Clitoria ternatea. App. Biochem. Biotechnol 173:682-693.

Al-Snafi, AE. 2013. Pharmacological importance of Clitoria ternatea- a review. IOSR Journal of Pharmacy 6(3)68-83.

Alves, CT, ICFR Ferreira, L Barros, S Silva, J Azeredo, and M Henriques. 2014. Antifungal activity of phenolic compounds identified in flowers from North Eastern Portugal against Candida species. Future Microbiol. 9(2), 139-146.

Anand, SP, A Doss and V Nandagopalan. 2011. Antibacterial studies on leaves of Clitoria ternatea Linn - a high potential medicinal plant. International Journal of Applied Biology and Pharmaceuticals Technology 2(3):453-456.

de Oliveira Filho, AA, HMB Fernandes, JP de Sousa, GL de Azevedo Maia, JMB Filho, TJCF de Assis, HLF Pêssoa, and EO Lima. 2017. Antifungal effect of flavonoid 5, 7, 4'trimethoxyflavone against Candida krusei Strains. Int. J. of Trop. Dis. \& Health 5(2): 136-140.

Jin, JM, and CR Yang. 2003. Two new spirostanol sapogenins from fermented leaves of Agave americana. Chin. Chem. Lett. 14:491-494.

Kamilla, L, SM Mansor, S Ramanathan, and S Saidharan. 2009a. Effects of Clitoria ternatea leaf extract on growth and 
morphogenesis of Aspergillus niger. Microscopy and Microanalysis 15:366-372.

Kamilla, L, SM Mansor, S Ramanathan, and S Sasidharan. 2009b. Antimicrobial activity of Clitoria ternatea (L.) extracts. Pharmacologyonline 1: 731-738.

Kelemu, S, C Cordona, and G Segura. 2004. Antimicrobial and insecticidal protein isolated from seeds of Clitoria ternatea (L.), a tropical forage legume. Plant Physiol. and Biochem. 42(11):867-873.

Kelemu, S, G Mahuku and G Segura. 2005. An antifungal protein of the tropical forage legume Clitoria ternatea controls diseases under field and greenhouse conditions. Phytopathol. 95(6): S52.

Mensah, R, D Leach, A Young, N Watts, and P Glennie. 2014. Development of Clitoria ternatea as a biopesticide for cotton pest management: assessment of product effect on Helicoverpa spp. and their natural enemies. The Neth. Entomol, Soc, Entomologia Experimentalis et Applicata 154: 131-145.

Naz, S, SQN Batool, and N Munir. 2013. Antifungal activity of Clitoria ternatea L. extracts against different fungal spesies. Mycopath 11(2):91-94.

Neela, D, G Ajoy, and C Padma. 2014. Antifungal effect of Clitoria ternatea L. leaf extract on seeds of Pisum sativum L. in relation to some biochemical parameters. International Journal of Research Ayuverda Pharmacy 5(4):536-539.

Nulik, J. 2009. Kacang kupu (Clitoria ternatea) leguminosa herba alternatif untuk sistem usahatani integrasi sapi dan jagung di Pulau Timor. Wartazoa 19(1):43-51.

Rao, AS, KL Sobha, PM D'Almeida, and KS Rai. 2016. In vitro antimicrobial activity of root extract of Clitoria ternatea. Proceedings of IASTEM International Conference, Sharjah, UAE, 3-4 December 2016.

Sutedi, E. 2013. Potensi kembang telang (Clitoria ternatea) sebagai tanaman pakan ternak. Wartazoa 23 (2): 51-62.

Suzuki, JK, TIE Svidzinski, TIE, CS Shinobu, LFA Silva, E Rodrigues-Filho, DAG Cortez, and ICP Ferreira. 2007. Antifungal activity of the extracts and saponins from Sapindus saponaria. Ann. of Brazilian Aca. of Sci. 79(4):577-583.

Syazwani BS. 2013. The Extraction of Anthocyanin From Clitoria ternatea (Blue Pea Flower) by Using Spray Dryer. Thesis, University Pahang Malaysia.

Umamaheswari, N, S Rhama, M Kannahi, and S Madhavan. 2010. Antifungal activities of Clitoria ternatea L. leaf extract. Ad. Plant Sci. 23(11): 377-378. 